\title{
天空放射輝度分布モデルを用いた日射遮蔽体の透過特性の評価 に関する研究 \\ EVALUATION OF TRANSMISSION CHARACTERISTICS OF SHADING DEVICE WITH SKY RADIANCE DISTRIBUTION MODEL
}

\author{
菊池卓郎*，井川憲 男** \\ Takuro KIKUCHI and Norio IGAWA
}

\begin{abstract}
Shading device is effective for reducing radiation load of buildings. Radiation load of buildings considering sky radiance distribution is different from that by isotropic model. RADIANCE is ray-tracing program and its accuracy is evaluated by some previous researches. In this research, RADIANCE installed sky radiance distribution model All Sky Model-R was developed. The transmission characteristics of external blinds evaluated by RADIANCE with isotropic model are compared with that with distribution mode in each sky conditions. Prediction error of annual insolation of building with external blinds by isotropic model is evaluated on the basis of that by sky distribution model. The evaluation results are introduced in this paper.
\end{abstract}

Keywords : sky radiance distribution, All Sky Model-R, simulation, RADIANCE, blinds 天空放射輝度分布，All Sky Model-R，シミュレーション，RADIANCE，ブラインド

\section{1.はじめに}

建築設計において建物のエネルギー使用量を低減することが重 要な課題となって久しい。エネルギー消費の抑制に、日射による熱 負荷を制御することが効果的であるため、本来目隠しや遮光の目的 で用いられるブラインドを、近年建物外部に設置し、より高い日射 遮蔽効果を期待する利用例が見られる。このような状況から、建物 の日射負荷と日射遮蔽体の日射遮蔽効果を高精度に予測すること は、エネルギー使用の合理的な設計に寄与すると考えられる。

日射は、太陽から直接地上に到達する直達日射と大気で散乱され て地上に到達する天空日射の 2 つ分けられ、天空日射は無視でき ない割合を占める。天空の放射輝度分布を考慮することの重要性は 古くから指摘されているが ${ }^{11} 、$ 建築の分野においては、放射輝度分 布の実測データを得ることが困難であることと計算上の簡便性か ら一様の放射輝度分布を想定して計算されることが多かった。

1993 年に Perez, R.らによって全天候型の天空輝度分布がモデル 化され2)、また 2004 年には井川らによって国内の測定データから 天空輝度分布モデル All Sky Model-L と天空放射輝度分布モデル All Sky Model-R が開発され ${ }^{3)} 、$ 気象データから可視光と日射の両方 の天空分布が推定可能となった。

また、光の挙動を高精度に予測する光線追跡法は、これまで一部 の研究者によってのみ扱われてきたが、米国ローレンスバークレー 国立研究所で開発された光線追跡法を用いた照明計算プログラム $\mathrm{RADIANCE}^{4)}$ が 2002 年にオープンソース化したことから、その利 用が国内外で広まっており、計算精度の検証事例もある5)。

本研究の目的は、全天候型放射輝度分布モデル All Sky Model-R （以下、分布モデル）を組み込んだ RADIANCE を開発し、外ブラ インドの透過特性を評価することである。ここでは、従来から使用
されてきた簡易モデルである一様天空モデル（以下、一様モデル） を比較対象とする。まず天空状態、太陽高度および外ブラインドの スラット角と反射特性をパラメータとして、外ブラインドを透過す る日射量と外ブラインドの透過率を算出する。さらに、南面、西面 および東面の 3 方位について自動制御された外ブラインドを想定 した年間計算を行うことで、年間を通した天空放射輝度分布の考慮 の有無による日射受照量を算出する。

\section{2. 既往の研究}

\section{1 天空放射輝度分布モデルを用いた日射受照量予測に関する研究}

Perez，R.らは観測される気象データから天空輝度分布を決定す る All-weather Model を開発している ${ }^{2)}$ 。また Mardaljevic, J. が開発 した RADIANCE 上で All-weather Modelによる天空輝度分布を生成 するプログラム ${ }^{6}$ を利用して、Anselmo, F.は天空の分布を考慮した 日射受照量の期間積算值を算出するツールを開発している7)。

また、Kittler, R.の提案する天空輝度分布モデル ${ }^{8)}$ 灾用して、細 淵らは放射輝度分布モデルとして利用することを試行している9 。 複数の天空輝度分布タイプを 5 つに集約寸ることである程度の推 定精度を維持しながら利便性を向上させている。

\section{2 指向特性を考慮した日射遮蔽体の透過特性に関する研究}

一ノ瀬らは形態係数を用いながら非均等拡散反射性状を扱う手 法を提案し、直達日射および一様分布モデルの天空日射を光源とし て遮蔽体の反射指向特性を考慮した透過特性を評価している ${ }^{10)}$ 。

西田らは、外ブラインドの反射指向特性を波長別に測定評価し、 直達日射について RADIANCE を用いて波長別に計算を行っている。 その結果を荷重平均して、太陽高度とスラット角度ごとに日射透過 率と反射率を求めている ${ }^{11)}$ 。
$*$ (株竹中工務店技術研究所 修士 (工学)
大阪市立大学大学院生活科学研究科 教授 $\cdot$ 博士 (工学)
R \& D Institute, Takenaka Corporation, M. Eng.

Prof., Graduate School of Human Life Science, Osaka City University, Dr. Eng. 


\section{3. 計算条件}

\subsection{RADIANCE の解析パラメータ設定}

RADIANCE の間接計算に関わるパラメータは、計算精度と計算 時間との比較検討を行った結果から、高精度設定と中精度設定の 2 つを決定する注1)。

\section{2 スラットの反射特性}

スラットに用いた平面の反射特性は、反射率 $0 \%$ 、反射率 $60 \%$ の 均等拡散面および反射率 $60 \%$ の非均等拡散面の 3 つである。非均 等拡散面は鏡面反射成分 $36 \%$ 、拡散反射成分を $64 \%$ 含むものとす る 注2)。図 1 に本研究で用いた均等拡散面と非均等拡散面の反射特 性関数 ${ }^{12)}$ を示す。

\section{3 モデル形状}

計算モデルは図 2 で示寸奥行き $97 \mathrm{~mm}$ のスラット断面に対して 約 20 倍の幅を持つブラインドで構成される。計算においては図 3 で示寸ようにスラットの幅方向の両端と奥行き方向の建物側に反 射率 $0 \%$ の平面を設定し、評価したい鉛直面方向以外から入射寸る 光を遮蔽する。地物による反射日射は、反射率 $20 \%$ の水平面をブ ラインド形状の底部に設置することで再現する。計算の簡易化のた め、スラットの曲面を図 4 に示すように複数に分割された平面で構 成する。図 5 にスラット曲面の分割数とブラインドの透過日射量お よび反射日射量の誤差の関係を示す。点線は実形状を示す。 RADIANCE の間接計算に関わるパラメータは高精度設定と寸る。 誤差は 40 に分割した場合（平面同士の成寸角度：2.0）の透過日 射量および反射日射量に対する相対誤差として示す注 ${ }^{3)}$ 。光源は入 射角 $40^{\circ}$ と $60^{\circ}$ の直達日射と、一様モデルによる天空日射とする。

光源が直達日射、天空日射のいずれの場合においても、分割数が 3 分割以下の場合 40 分割の場合と比べて透過日射量が大きく、反 射日射量が小さい傾向がある。相対誤差の絶対值が 5 分割で最大 $7 \% 、 9$ 分割で最大 $3 \% 、 20$ 分割で最大 $1 \%$ まで小さくなる。本研究 では 9 分割を採用する。

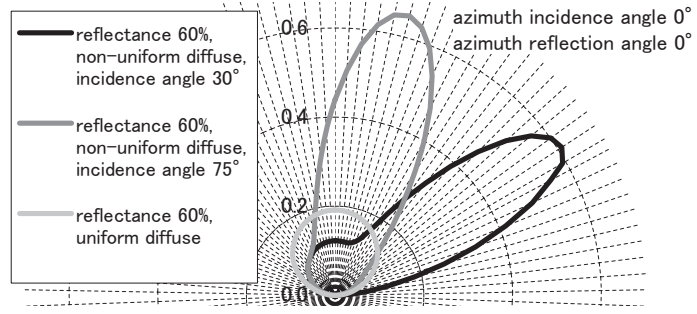

図 1 スラットを構成する平面の反射特性関数＼cjkstart単位 $[1 / \mathrm{sr}]$

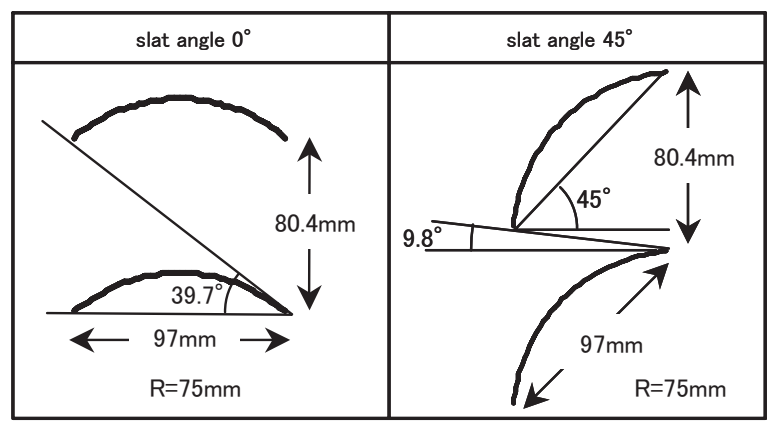

図 2 ブラインド断面形状

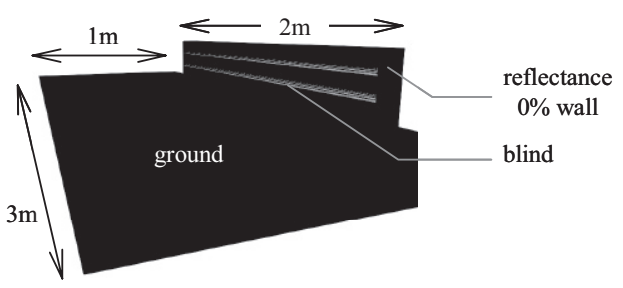

図 3 計算モデル概観図

\begin{tabular}{|c|c|c|c|c|c|c|c|}
\hline 分割数 & 1 & 2 & 3 & 5 & 9 & 20 & 40 \\
\hline 断面図 & - & & & & & & \\
\hline $\begin{array}{c}\text { 平面同士 } \\
\text { の成す角度 }\end{array}$ & - & 40.2 & 26.8 & 16.1 & 8.9 & 4.0 & 2.0 \\
\hline
\end{tabular}

図 4 スラット曲面の分割数

$\diamond-$ non-uniform diffuse, slat angle $0^{\circ}$
$\Delta-$ non-uniform diffuse, slat angle $45^{\circ}$
$-\diamond-$ uniform diffuse, slat angle $0^{\circ}$
$-\Delta-$ - uniform diffuse, slat angle $45^{\circ}$
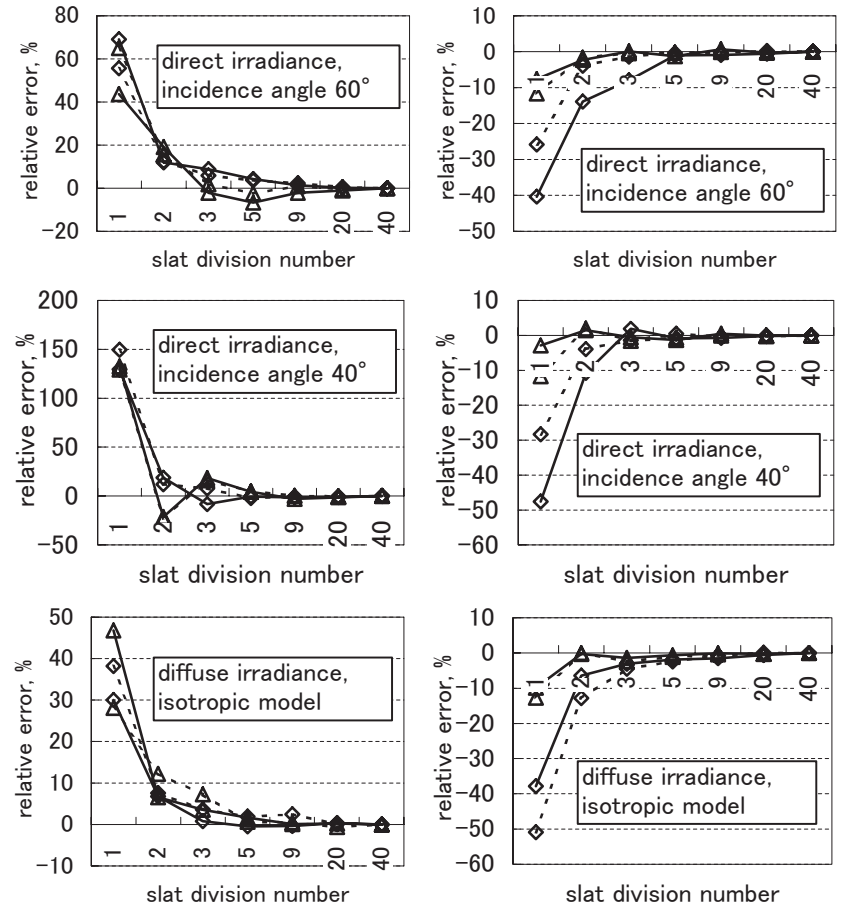

(a)透過日射量

(b)反射日射量

図 5 スラット曲面の分割数と

ブラインドの透過日射量および反射日射量の誤差

\section{4. 外ブラインドの天空状態による透過特性の評価 4.1 鉛直面入射日射量の評価}

All Sky Model-R は、晴天指標 Kc と清澄指標 Cle から天空指標 Sky Index（以下、 $\mathrm{Si}$ ）を求め注 ${ }^{4}$ 、太陽高度と $\mathrm{Si}$ から相対天空輝度 分布を決定する ${ }^{3)}$ 。 Kc は全天日射量が大きいほど大きく、Cle は直 達日射量が大きいほど大きい。Si は量天空から晴天空にかけて、0 から 2（2 を超える場合もある）のあいだの值をとる。ここでは Kc と Cle のマトリックスから現実的に発生し得る天空状態を既往の 研究 ${ }^{3)}$ を参考に抽出し、分布モデルと一様モデルの鉛直面日射量を 比較する。本論文では $\mathrm{Si}$ を用いて便宜上、晴天空(clear sky : $\mathrm{Si}>1.7$ )、 
近晴天空(near clear sky : $1.7 \geqq \mathrm{Si}>1.5$ )、中間天空(intermediate sky : 1.5 $\geqq \mathrm{Si}>0.6$ )、近曇天空(near overcast sky : $0.6 \geqq \mathrm{Si}>0.3$ ) および晴天空 (overcast sky : $0.3 \leqq \mathrm{Si}$ )の 5 つに分類する。なお、図 6 に対象とした 天空状態とその $\mathrm{Si}$ を示す。

図 7 に代表的な天空状態について分布モデルで生成した太陽高 度 $45^{\circ}$ の場合の天空放射輝度分布と、同じ天空日射量となる一様 モデルによる天空放射輝度を示す。一様モデルの天空放射輝度は分 布モデルより、曇天空（ $\mathrm{Kc}=0.1 、 \mathrm{Cle}=0)$ では低高度で大きく、高 高度で小さい。分布モデルでは晴天空に近づくにつれ、太陽位置周 辺の放射輝度が相対的に大きくなり、また晴天空 $(\mathrm{Kc}=1 、 \mathrm{Cle}=1)$ では地平線近傍の放射輝度が一様モデルによる放射輝度を上回る。

ここでは、鉛直面と太陽の方位角が同一の場合について比較する。 RADIANCE の間接計算に関わるパラメータは高精度設定とする。

地物反射を含む全天日射の鉛直面入射日射量について、太陽高度 $30^{\circ}$ の天空状態別の誤差を図 8 に示す。一様モデルは分布モデルよ り曇天空では大きく、晴天空に近いほど小さい傾向にある。 Kc が 0.7 から 0.9、Cle が 0.3 から 0.6 の中間天空と近晴天空において誤 差が大きく、絶対誤差が-180 から-120W/m² 相対誤差が-30 から $-20 \%$ と大きく負の值をとる。図 9 に示寸太陽高度が $75^{\circ}$ のときの 誤差は、曇天空から近晴天空にかけて一様モデルのほうが大きい。

図 10 に代表的な天空状態として、曇天空 $(\mathrm{Kc}=0.1 、 \mathrm{Cle}=0)$ 、近 曇天空 $(\mathrm{Kc}=0.2 、 \mathrm{Cle}=0.1)$ 、中間天空 $(\mathrm{Kc}=0.6 、 \mathrm{Cle}=0.3)$ 、近晴天 空 $(\mathrm{Kc}=0.8 、 \mathrm{Cle}=0.6)$ および晴天空（ $\mathrm{Kc}=1 、 \mathrm{Cle}=1 ）$ の太陽高度に よる相対誤差と絶対誤差を示す。暑天空において相対誤差は太陽高 度によらず、約 $23 \%$ の值を示す。中間天空から晴天空にかけて太 陽高度が低いほど誤差は負の值をとる傾向がある。中間天空から近

\begin{tabular}{|c|c|c|c|c|c|c|c|c|c|c|}
\hline & \multicolumn{10}{|l|}{$\mathrm{Kc}$} \\
\hline $\mathrm{Cle}$ & 0.1 & 0.2 & 0.3 & 0.4 & 0.5 & 0.6 & 0.7 & 0.8 & 0.9 & 1 \\
\hline 0 & 0.10 & 0.20 & 0.30 & 0.40 & & & & & & \\
\hline 0.1 & & 0.52 & 0.62 & 0.72 & 0.82 & & & & & \\
\hline 0.2 & & & & 0.85 & 0.95 & 1.05 & & & & \\
\hline 0.3 & & & & & 1.05 & 1.15 & 1.25 & & & \\
\hline 0.4 & & & & & & 1.23 & 1.33 & & & \\
\hline 0.5 & & overca & sky & & & 1.31 & 1.41 & 1.51 & & \\
\hline 0.6 & & near or & rcast & & & & 1.47 & 1.57 & 1.67 & \\
\hline 0.7 & & interme & iate $\mathrm{s}$ & & & & 1.54 & 1.64[ & 1.74 & \\
\hline 0.8 & & near cl & ar sky & & & & 1.59 & 1.69 & 1.79 & 1.89 \\
\hline 0.9 & & clear s & & & & & 1.65 & 1.75 & 1.85 & 1.95 \\
\hline 1 & & & & & & & & 1.80 & 1.90 & 2.00 \\
\hline
\end{tabular}

図 6 本研究で対象とした $\mathrm{Kc}$ と $\mathrm{Cle}$ に対応する $\mathrm{Si}$ と天空状態

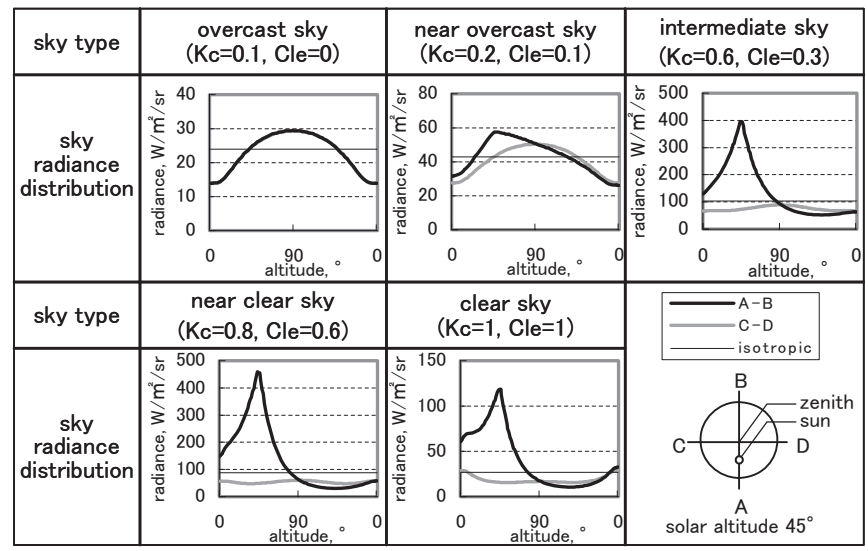

図 7 天空状態別の天空放射輝度分布の例

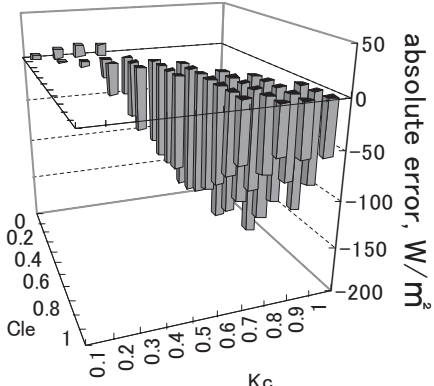

(a)絶対誤差

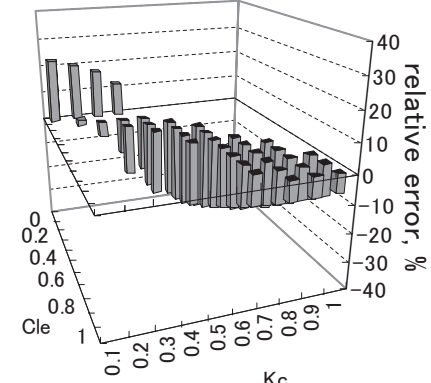

(b)相対誤差
図 8 太陽高度 $30^{\circ}$ における鉛直面入射日射量の誤差 (a)絶対誤差

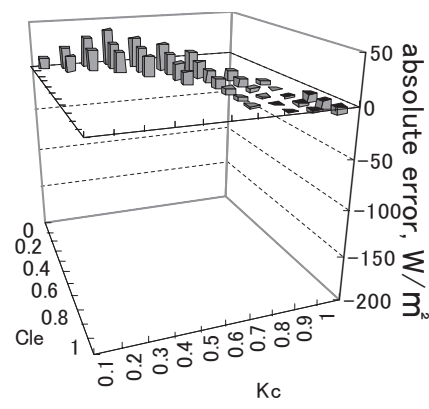

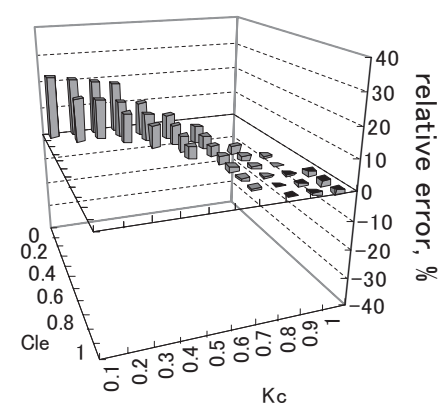

(b)相対誤差
図 9 太陽高度 $75^{\circ}$ における鉛直面入射日射量の誤差

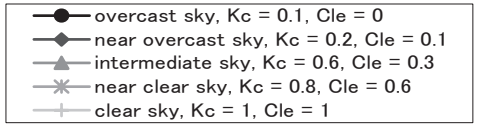

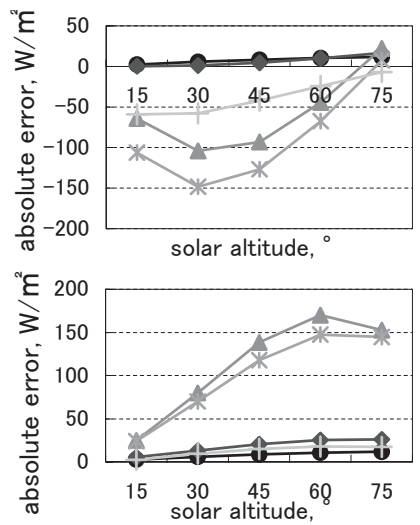

(a)絶対誤差

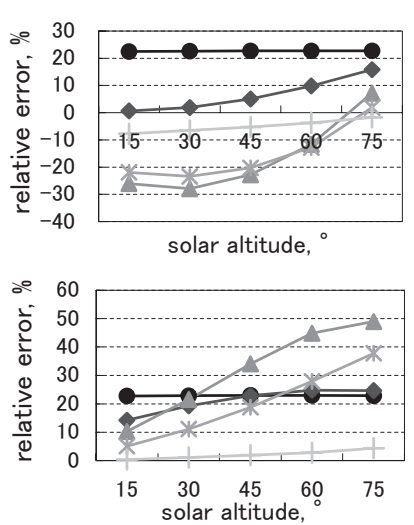

(b)相対誤差
図 10 太陽高度と鉛直面入射日射量の誤差の関係

（上段：鉛直面が太陽の方位角と同じ場合

下段 : 鉛直面が太陽の方位角と $180^{\circ}$ 逆の方位角の場合)

晴天空の太陽高度 $30^{\circ}$ のときに誤差が最大となる。太陽の方位角 と $180^{\circ}$ 逆の方位角の鉛直面では太陽高度が高いほど誤差は正の 值をとる。

\section{2 ブラインド透過日射量の評価}

地物反射を含む全天日射の透過日射量について、天空状態別の誤 差を太陽高度 $30^{\circ}$ について図 11 に、太陽高度 $75^{\circ}$ について図 12 に示す。ここではブラインドのスラット角度は $0^{\circ}$ 、反射特性は反 


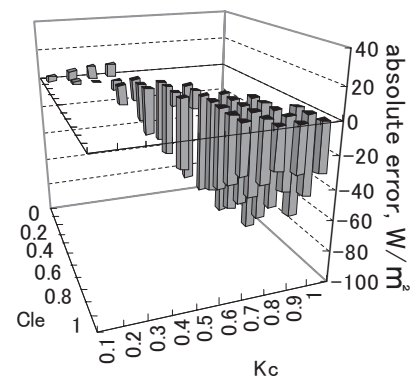

(a)絶対誤差

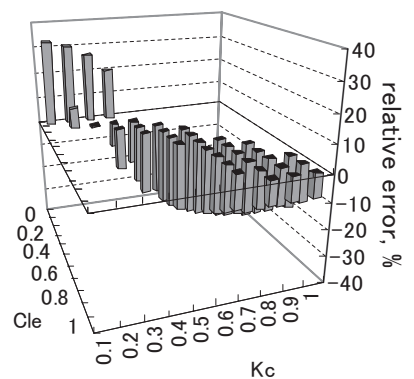

(b)相対誤差
図 11 スラット角 $0^{\circ}$ 、太陽高度 $30^{\circ}$ における透過日射量の誤差

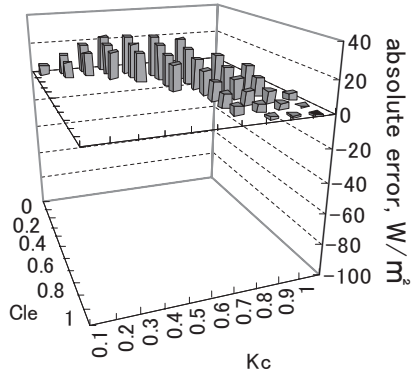

(a)絶対誤差

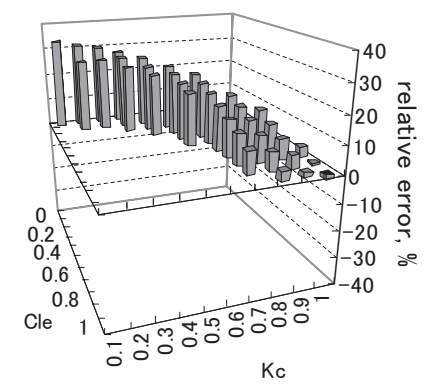

(b)相対誤差
図 12 スラット角 $0^{\circ}$ 、太陽高度 $75^{\circ}$ における透過日射量の誤差

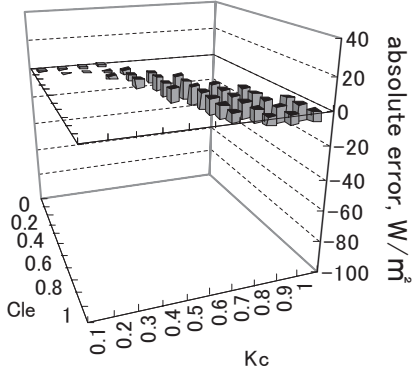

(a)絶対誤差

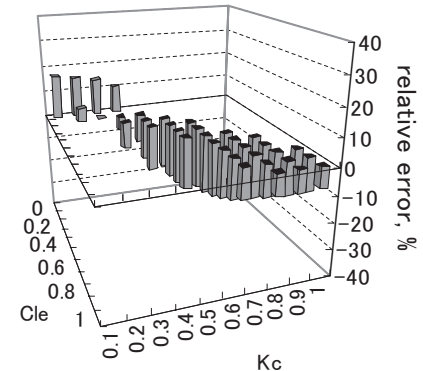

(b)相対誤差
図 13 スラット角 $45^{\circ}$ 、太陽高度 $30^{\circ}$ における透過日射量の誤差

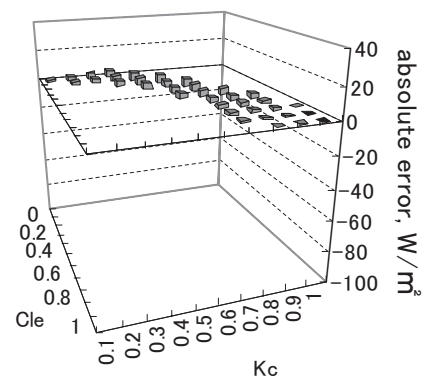

(a)絶対誤差

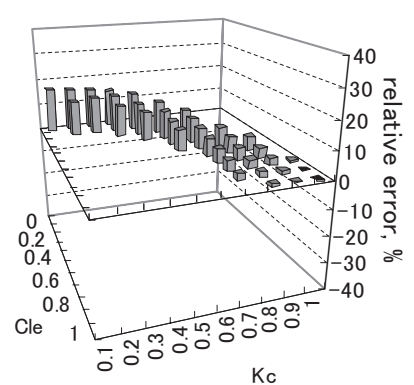

(b)相対誤差
図 14 スラット角 $45^{\circ}$ 、太陽高度 $75^{\circ}$ における透過日射量の誤差

射率 $60 \%$ の非均等拡散とする。天空状態と相対誤差との関係は、 鉛直面入射日射と似た傾向であるが、量天時で相対誤差が約 $33 \%$ 一様モデルのほうが大きく、太陽高度が高い $75^{\circ}$ では、曇天空か ら近晴天空にかけての正の相対誤差が鉛直面日射より大きい。
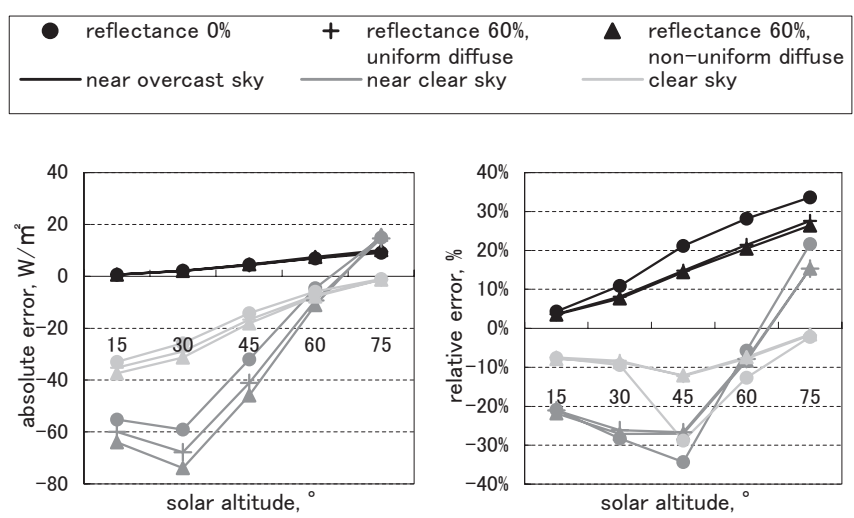

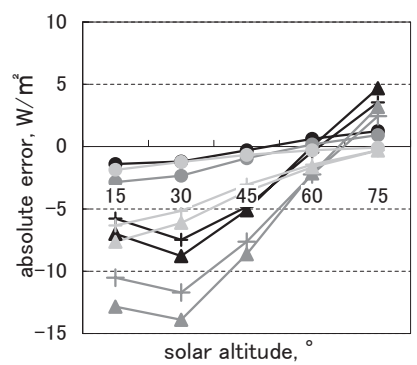

(a)絶対誤差

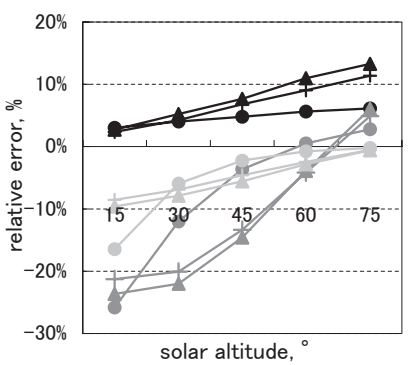

(b)相対誤差
図 15 太陽高度と透過日射量の誤差

(上段 : スラット角 $0^{\circ}$ 、下段 : スラット角 $45^{\circ}$ )

絶対誤差は、鉛直面入射日射と同様に中間天空と近晴天空時に大き く、太陽高度 $30^{\circ}$ のとき最大で約 $-90 \mathrm{~W} / \mathrm{m}^{2}$ 、太陽高度 $75^{\circ}$ のとき最 大で約 $25 \mathrm{~W} / \mathrm{m}^{2}$ を示す。スラット角 $45^{\circ}$ の結果を図 $13 、 14$ に示す。 透過する絶対量が小さいため絶対誤差は小さい。また、相対誤差は 直達日射を含めた多重反射による透過が卓越するために、天空日射 の分布の影響が弱まり鉛直面入射日射の相対誤差に近い。

図 15 に代表的な天空状態として、近㬝天空 $(\mathrm{Kc}=0.2 、 \mathrm{Cle}=0.1)$ 、 近晴天空（ $\mathrm{Kc}=0.8 、 \mathrm{Cle}=0.6 ） 、$ 晴天空 $(\mathrm{Kc}=1 、 \mathrm{Cle}=1)$ での、スラ ットを構成する面の反射特性別に太陽高度と誤差の関係を示す。

反射率 $0 \%$ 条件下では、太陽高度が低く、かつ直達日射がスラッ 卜間を直接通り抜けない太陽高度 (スラット角 $0^{\circ}$ のとき $45^{\circ}$ 、ス ラット角 $45^{\circ}$ のとき $15^{\circ}$ ）において太陽周辺の高い天空放射輝度 の影響を強く受けるため絶対誤差、相対誤差ともに大きい。透過日 射量の絶対值が小さい太陽高度の高い条件下では、地平線付近の天 空放射輝度は一様モデルのほうが小さいために大きな相対誤差が 生じるが、絶対誤差は大きくない。

反射率 $60 \%$ の条件下では鉛直面入射日射量における誤差と似た 傾向となる。反射率 $0 \%$ 条件下と比べると同じ太陽高度で相対誤差 が最大となる。また、均等拡散と非均等拡散の違いによる差は近晴 天空と晴天空の太陽高度が低いときに大きい。

\section{3 ブラインド透過率の評価}

天空日射のブラインド透過率について、太陽高度別に天空状態と の関係を図 16 に示す。ここでは地物反射は含まない。天空日射の 透過率は天空の相対的な放射輝度分布に依存し、All Sky Model-R は Si によって天空の相対的な放射輝度分布が決まるため、天空状 態は Si を指標とする。同時に一様モデルでの透過率を示す。晴天 空に近いほど、透過率は大きくなる傾向にあり、太陽高度が低いほ 
どその傾向が強くなるのは透過日射量の相対誤差と同様である。一 様モデルによる透過率は曇天空時や太陽高度の高い曇天空時から 近晴天空時にかけて分布モデルより大きな值を示すが、太陽高度の 低い中間天空から晴天空にかけて小さい值をとる。スラット角 $0^{\circ}$ と $45^{\circ}$ とでは、 $45^{\circ}$ のほうが全体的に透過率が低いため、天空状 態による透過率の差は小さい。スラットの反射特性が異なると透過 率は差があるが、スラット間を直接通り抜ける割合が大きいスラッ 卜角 $0^{\circ}$ ではその差は量天空と晴天空とにおいてほとんど変わら ない。一方、スラットで多重反射して間接透過する割合が大きいス ラット角 $45^{\circ}$ では、反射率 $60 \%$ の特に非均等拡散において一様モ デルの透過率と分布モデルの晴天空における透過率の差が大きい。

次に地物反射を含む全天日射の透過率を、太陽高度 $30^{\circ}$ と $75^{\circ}$ について天空状態との関係を図 17 に示す。ここでのスラットの反 射特性は $60 \%$ 反射率の非均等拡散面だけ示す。天空日射の透過率 において、スラット角 $0^{\circ}$ 、太陽高度 $30^{\circ}$ の中間天空から晴天空の ときに、一様モデルによる天空日射の透過率が分布モデルよりかな り小さい值を示していたが、全天日射の透過率としては直達日射が スラット間を直接通り抜ける太陽高度であるために天空日射の影 響が小さくなり、その違いは小さい。太陽高度が高い $75^{\circ}$ の中間 天空で最大約 $5 \%$ の差が見られる。スラット角 $45^{\circ}$ では天空日射の 透過率の誤差が大きくないことと、直達日射がスラット間を直接透 通り抜ける割合が卓越寸るために両者の差は小さい。

\begin{tabular}{|cccccc|}
\hline+ & solar altitude $75^{\circ}$ & $\circ$ & solar altitude $60^{\circ}$ & $\times$ & solar altitude $45^{\circ}$ \\
$\Delta$ & solar altitude $30^{\circ}$ & $\boldsymbol{*}$ & solar altitude $15^{\circ}$ & & isotropic model \\
\hline
\end{tabular}
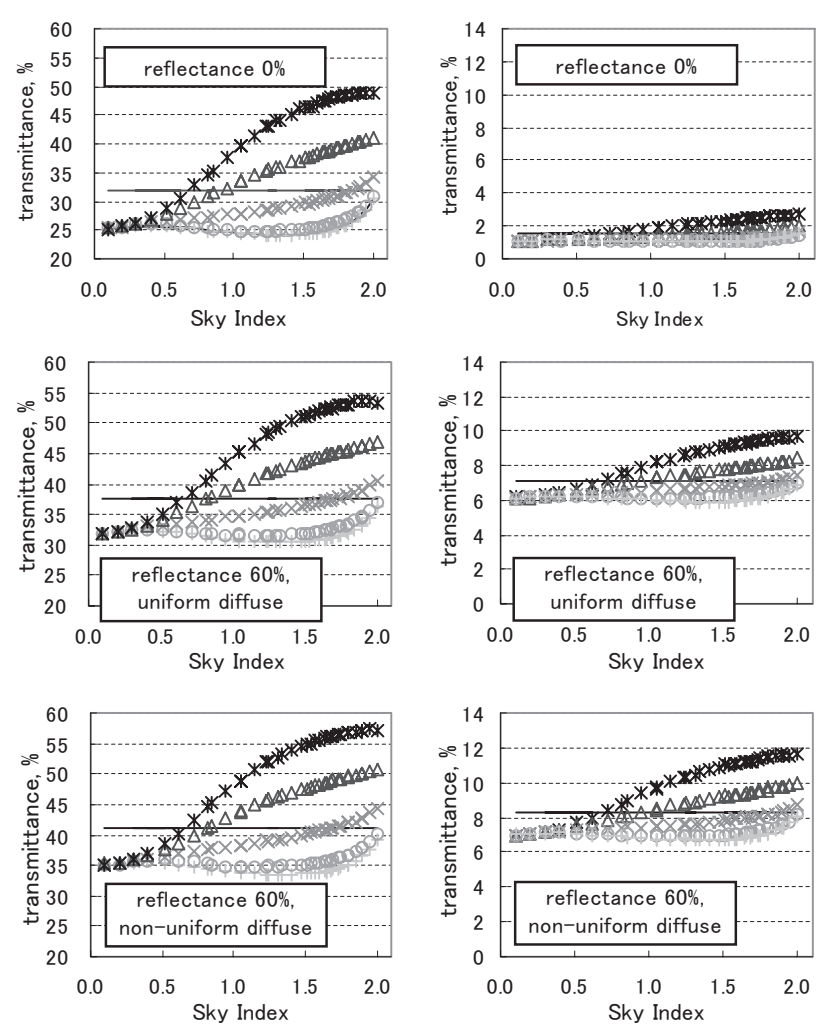
（a）スラット角 $0^{\circ}$
（b）スラット角 $45^{\circ}$

図 16 天空状態と天空日射透過率

\section{5. 外ブラインドの年間を通した透過特性の評価}

4 章において、一様モデルで外ブラインドの透過日射量と透過率 を予測した場合の天空状態別の誤差が示された。そこで、拡張アメ ダス気象データ $\left.{ }^{13}\right)$ から東京（緯度：35.7 、経度 : $139.8^{\circ}$ ）の標 準年を用いて年間の日射受照量予測を行い比較する。スラットの反 射特性は反射率 $60 \%$ の非均等拡散面とする。RADIANCE の間接計 算に関わるパラメータは中精度設定とする。
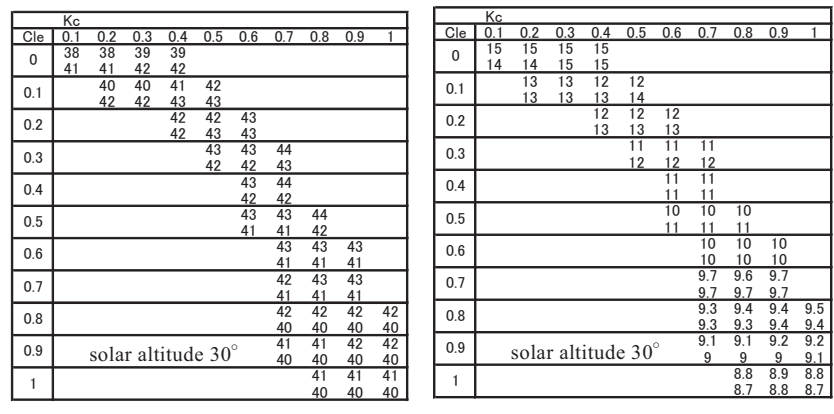

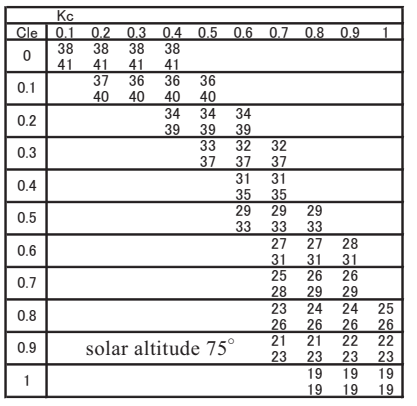

（a）スラット角 $0^{\circ}$

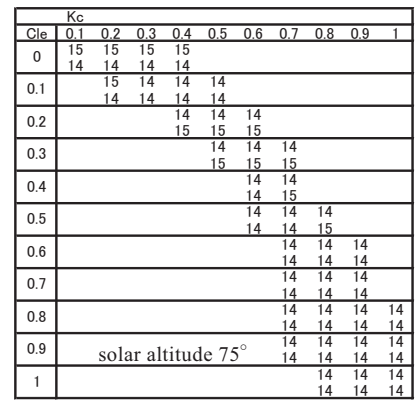

(b) スラット角 $45^{\circ}$
図 17 天空状態と全天日射透過率 単位[\%]

(セル上段：分布モデル、セル下段：一様モデル)

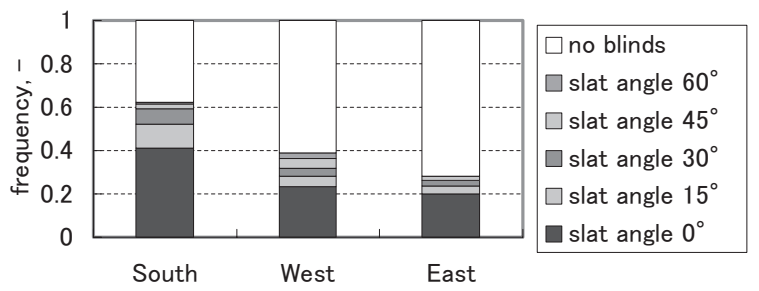

図 18 スラット角と開放状態の出現頻度

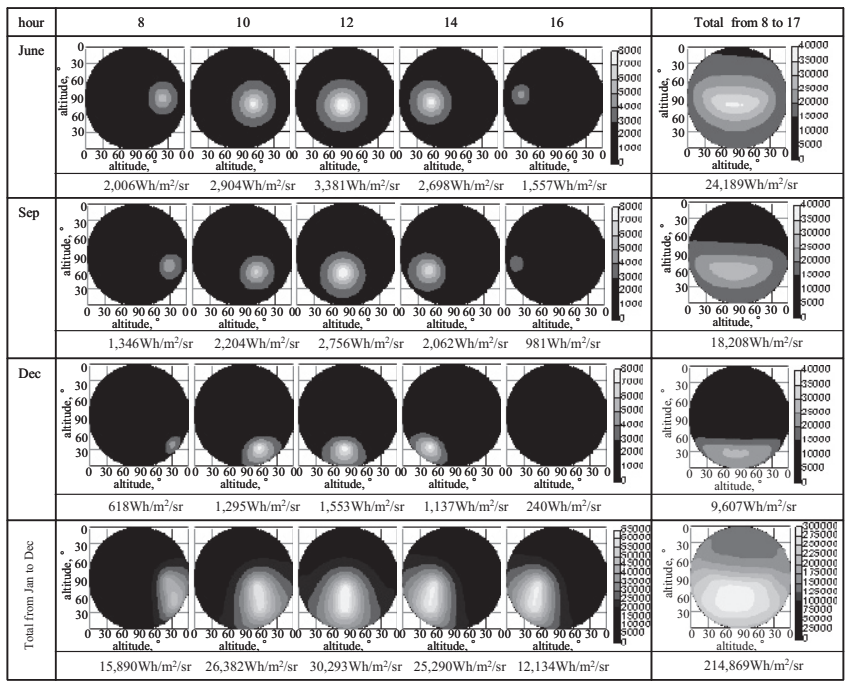

図 19 期間積算した天空放射輝度分布

(セル上段: 分布モデル、セル下段：一様モデルの平均放射輝度) 


\section{5. 外ブラインドの年間を通した透過特性の評価}

4 章において、一様モデルで外ブラインドの透過日射量と透過率 を予測した場合の天空状態別の誤差が示された。そこで、拡張アメ ダス気象データ ${ }^{13)}$ から東京（緯度：35.7 、経度 : $139.8^{\circ}$ ）の標 淮年を用いて年間の日射受照量予測を行い比較する。スラットの反 射特性は反射率 $60 \%$ の非均等拡散面とする。RADIANCE の間接計 算に関わるパラメータは中精度設定とする。

ここで、南面、西面、東面の 3 方位について、自動制御された外 ブラインドが設置された鈆直面を想定する。スラット角度の制御方 法は、 $0^{\circ}$ から $60^{\circ}$ までのあいだを $15^{\circ}$ ピッチで稼動し、直達日射 を完全に遮蔽する角度を選択する。保護角は設けない。太陽位置ま たは天候状態により直達日射を受照しない時には外ブラインドは 開放状態とする。図 18 にスラット角と開放状態の出現頻度を示す。

\section{1 鉛直面入射日射量の評価}

図 19 に代表的な月（6月、9 月、12 月および 1 月から 12 月まで の積算） と時間（8 時、10 時、12 時、14 時、16 時および 8 時から 17 時までの積算）に発生した天空放射輝度を積算した分布図を示 す。いずれの分布図においても、睛天空に見られる地平線近傍で放 射輝度が高くなる分布は、量天空と積算されることでその傾向が弱 まるが、太陽位置を中心にした強い分布は存在し、一様モデルによ る分布とは大きく異なる。

図 20 に 1 月から 12 月、 8 時から 17 時までの毎月毎時の鉛直面 入射日射量について、その積算值の誤差を示す。南面は太陽高度の 高い 6 月に正の誤差が最大化し、太陽高度の低い冬期の 12 時前後 で負の誤差が最大化する。西面は、夏期の午前に正の誤差が大きく、 夏期の午後に負の誤差が大きい。東面は逆に午前に負の誤差が大き く、夏期の午後に正の誤差が大きい。北面は年間通して正の誤差が 大きく、特に 6 月を除く夏期の 12 時前後が大きい。

\section{2 ブラインド透過日射量の評価}

図 21 に 1 月から 12 月、 8 時から 17 時までの毎月毎時の透過日 射量について、その積算值の誤差を示す。全体的な傾向は鉛直面入 射日射量と似ている。直達日射の入射する南面の午前と午後や西面 の午後、東面の午前においてブラインドが存在する頻度が高い。そ のため日射量の絶対量が減少し、鉛直面入射日射量の絶対誤差と比 べると小さい。ただし、入射日射量の増加または減少割合よりも透 過日射量の増加または減少割合のほうが大きいため、南面において 鉛直面入射日射量の相対誤差よりも大きな值を示す。

\section{3 ブラインド透過率の評価}

図 22 に一様モデルと分布モデルで求めた天空および全天日射の 透過率の相関を示す。一様モデルは方位では誤差の傾向にほとんど 差がないため方位の区別はしない。分布モデルにより求められた透 過率は、天空状態によって異なるためにばらつきがある。ばらつき はスラット角が大きいほど大きい。分布モデルによる透過率の平均 值は、スラット角 $0^{\circ}$ を除いて一様天空による透過率よりも大きい 值を示す。スラット角 $0^{\circ}$ は約 $40^{\circ}$ 以上の太陽のプロファイル角の ときに設定される角度であるため、より広い範囲の太陽位置で出現 する。したがって透過率も広い範囲に存在し、一様モデルによる透 過率より大きい值にも存在するが、平均值は一様モデルによる透過 率より小さい。

全天日射の透過率も天空日射の透過率と同様の傾向を示すが、全
体的にばらつきの範囲が狭くなる。分布モデルの天空日射の透過率 がスラット角 $0^{\circ}$ で一様モデルの透過率より大きくなる傾向は直 達日射の影響によって弱まる。
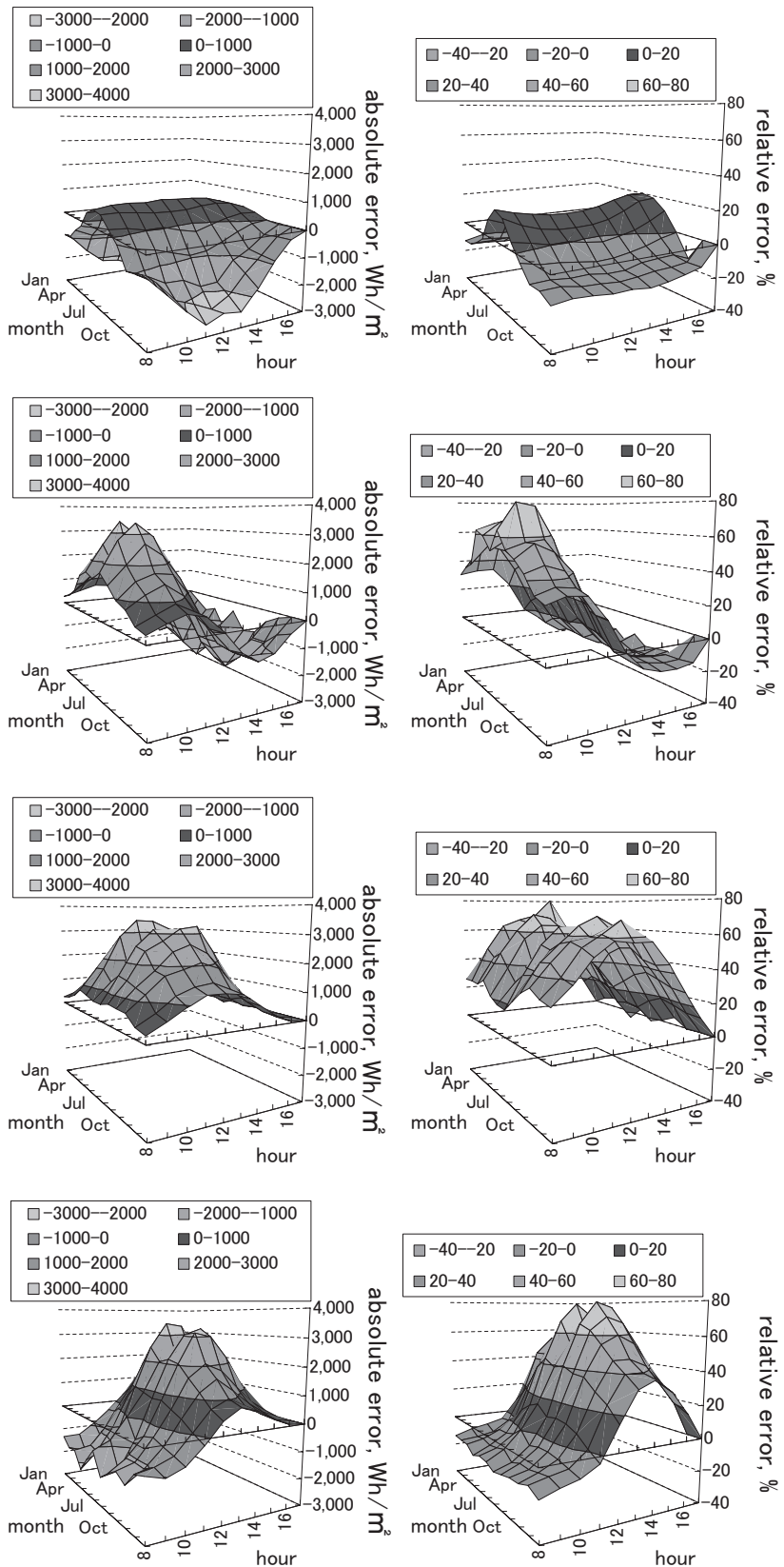

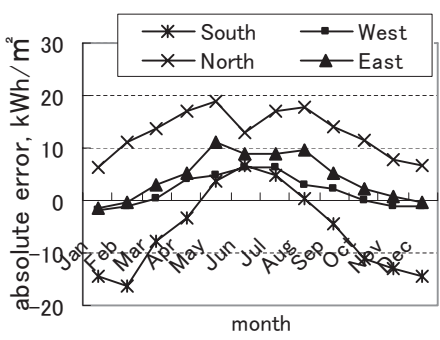

(a)絶対誤差

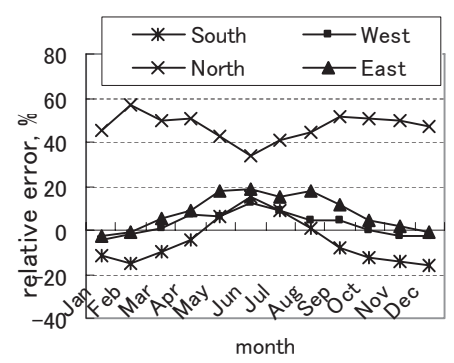

(b)相対誤差
図 20 積算鉛直面入射日射量の誤差

（上から、南面、西面、北面、東面、月積算） 
図 21 で示した誤差は入射日射量の違いと透過率の違いの両方を 含んだ誤差である。分布モデルと一様モデルで求められた透過率の 違いが透過日射量の推定に与える影響を比較するために、天空日射 による入射日射量は分布モデルと一様モデルとで同じとし、透過率 のみ分布モデルと一様モデルで得られた值を用いて透過日射量を 求める。入射日射量は分布モデルによって求められた值を用いる。 図 23 に示すように南面は夏期の 12 時前後、西面は夏期の 13 時前 後、東面は夏期の 10 時前後で約 $10 \%$ 一様モデルのほうが大きい。 これは各方位の太陽のプロファイル角が大きい時間帯と一致する。 一方、南面は冬期の特に 12 時前後、西面は冬期の 15 時前後、東面

\begin{tabular}{|ll|}
$\square-3000--2000$ & $\square-2000--1000$ \\
$\square-1000-0$ & $\square 0-1000$ \\
$\square 1000-2000$ & $\square 2000-3000$ \\
$\square 3000-4000$ & \\
\hline
\end{tabular}
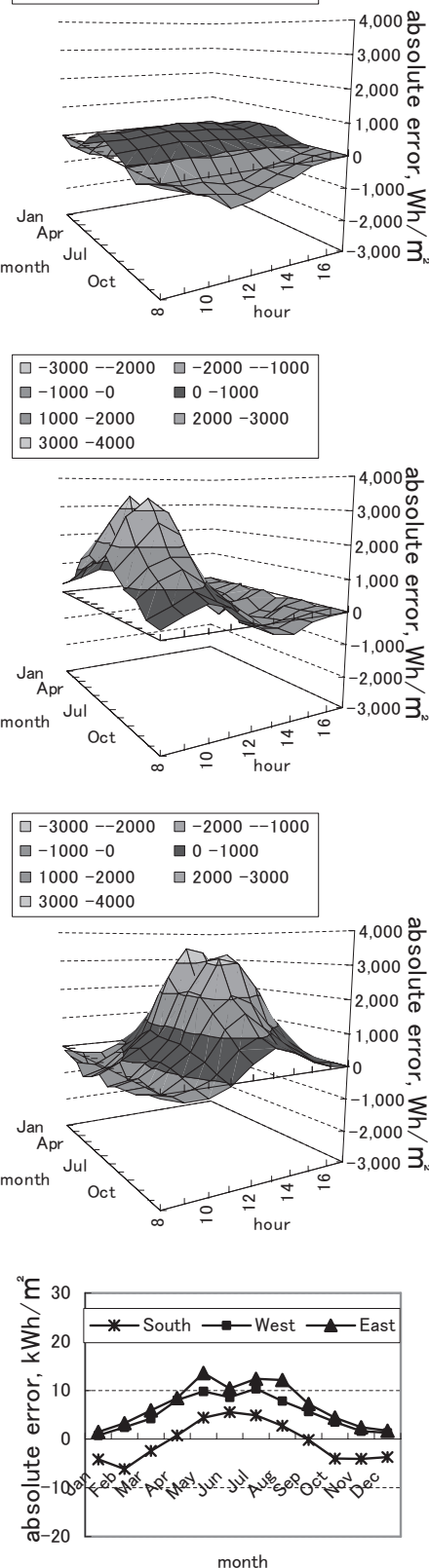

(a)絶対誤差
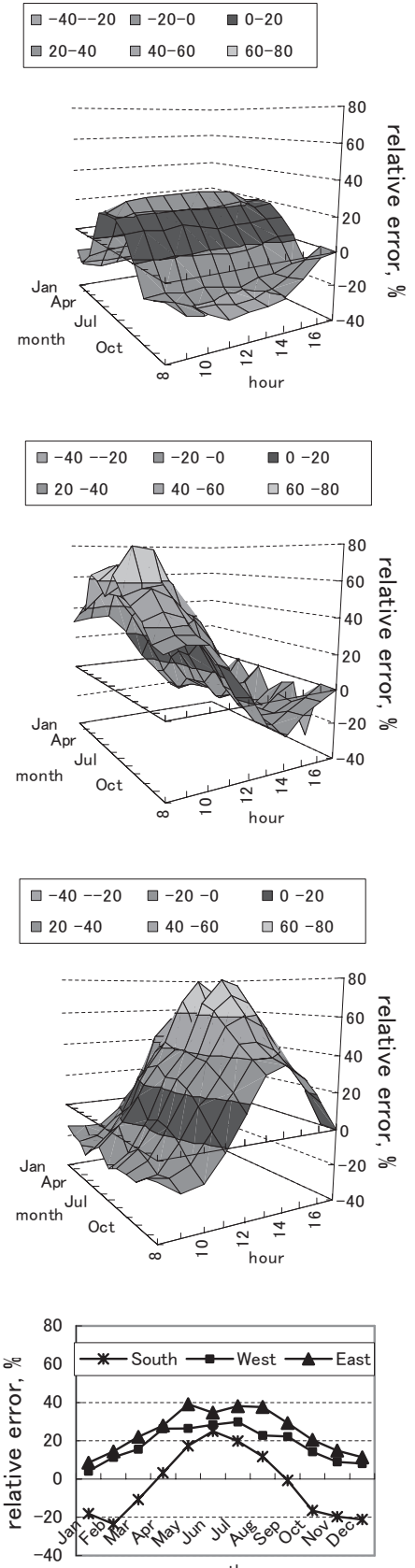

(b)相対誤差
図 21 積算透過日射量の誤差

（上から、南面、西面、東面、月積算）

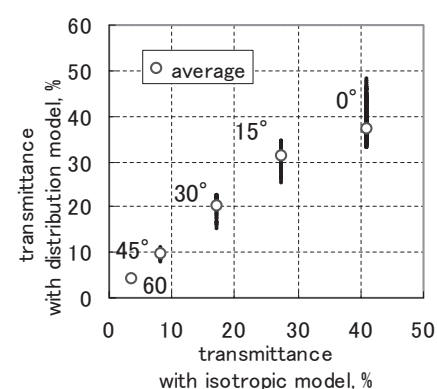

(a)天空日射

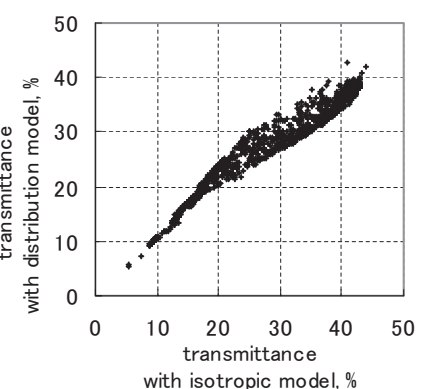

(b)全天日射
図 22 一様モデルと分布モデルによる透過率の相関
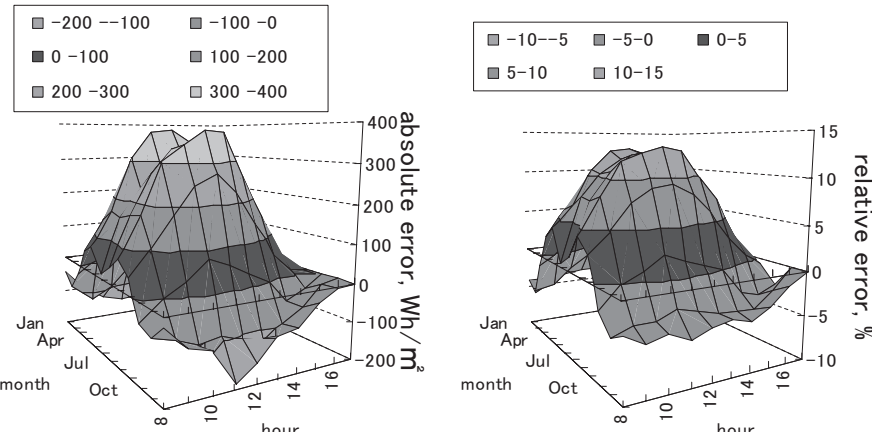

$\begin{array}{|ll|}\square-200--100 & \square-100-0 \\ \square 0-100 & \square 100-200 \\ \square 200-300 & \square 300-400\end{array}$

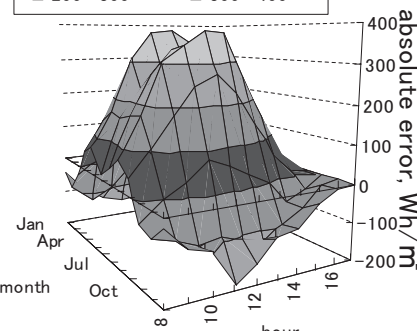

$\begin{array}{ll}\square-200--100 & \square-100-0 \\ \square 0-100 & \square 100-200 \\ \square 200-300 & \square 300-400\end{array}$
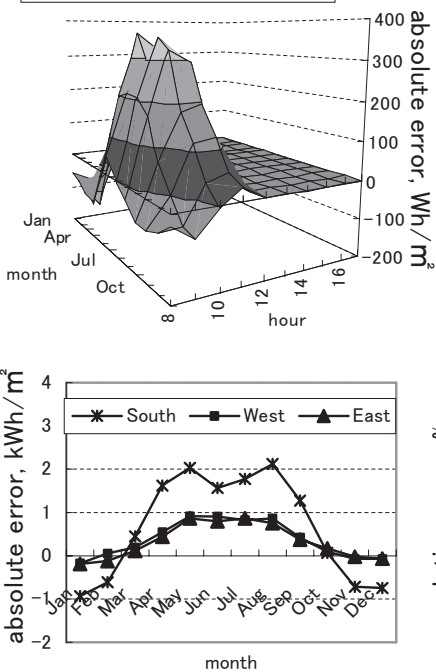

(a)絶対誤差
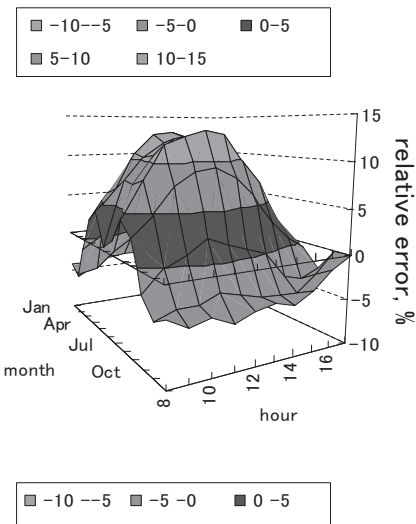

$\square 5-10 \quad \square 10-15$
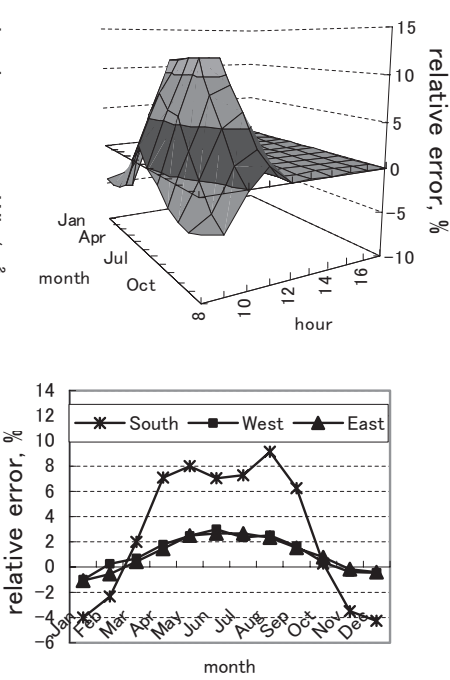

(b)相対誤差
図 23 透過率の違いによる積算透過日射量の誤差 (上から、南面、西面、東面、月積算) 
は冬期の 9 時前後で一様モデルのほうが小さい。これは各方位の太 陽のプロファイル角が小さい時間帯と一致する。月積算で比較する と、夏期をピークとして中間期までの期間にわたって一様モデルの ほうが大きい。

\section{6. まとめ}

光線追跡法による照明計算プログラム RADIANCE に、気象デー タから天空放射輝度分布を決定できるモデル All Sky Model-R を組 み込んだプログラムを開発した。これにより天空放射輝度分布と建 材の反射特性の双方を考慮した詳細な日射遮蔽体の効果を予測す ることが可能になった。また、気象データから天空放射輝度分布を 推定できるため、気象データを用いた年間の日射受照予測が可能と なり、日射遮蔽体を有する建物のより詳細な年間負荷予測を行う見 通しを得た。外ブラインドの透過日射量および透過率について、い くつかの天空状態とスラットの角度および反射特性の条件下で、一 様天空モデルによって計算した場合と比較評価を行った。得られた 知見の主要なものを以下に示寸。

・ 一様モデルで予測された外ブラインドを透過する日射量は、 分布モデルで予測された值と比較すると、太陽高度が高いとき の晴天空から近晴天空で大きい。また太陽高度が低いときの近 晴天空や晴天空で小さいが、直達日射が直接入射する太陽位置 では相対誤差は小さくなる。鉛直面に入射する日射量の誤差と 比較すると、絶対量が減るため絶対誤差は小さいが、相対誤差 は大きい。最大熱負荷計算を行う際、一様モデルを用いて鉛直 面日射量を推定することに大きな誤差を生じることが示された。 ・従来、ブラインドの天空日射の透過率は一様モデルをもちい て評価されてきたが、分布モデルで評価した場合と異なること が示された。一様モデルで予測された外ブラインドの天空日射 の透過率は分布モデルで予測された透過率と比べ、曇天空では 大きく、睛天空に近くかつ太陽高度が低いほど小さい。全天日 射の透過率で比較すると直達日射がスラット間を直接通り抜け る太陽高度のときでは透過率の差は小さく、太陽高度が高いと きの中間天空と近晴天空で一様モデルのほうが大きい。

・拡張アメダスの東京標準年気象データを用いて年間の日射受 照量予測を行った結果、年間を通して鉛直面入射日射量に大き な誤差が生じ、天空放射輝度の分布を考慮することの重要性が 示された。透過日射量においても、入射日射量に比べて絶対量 が小さいために絶対誤差は小さくなるが、大きな誤差が生じた。 南面において相対誤差が大きくなることが分かった。

・分布モデルと一様モデルで求められた透過率の違いを対象に 年間の透過日射量の予測值を比較した結果、南面の夏期におい て相対誤差が最大約 $10 \%$ 一様モデルのほうが大きく、また冬期 においては一様モデルのほうが小さくなる傾向が示された。

・ あらゆる天候状態が出現する中で、ある期間における日射負 荷や空調消費エネルギーを予測する際に、一様モデルを用いる と大きな推定誤差を生じるため、実際の現象に対する再現性の 高い分布モデルを使用寸る必要性が確認された。
定した ${ }^{14)}$

高精度設定で、 $a b=4, a a=0.2, a r=64, a d=2048, a s=512$

中精度設定で、 $\mathrm{ab}=4, \mathrm{a}=0.2, \mathrm{ar}=64, \mathrm{ad}=1024, \mathrm{as}=512$

注 2) RADIANCE のマテリアルパラメータの設定は specularity $=0.36$, roughness $=0.18$ である ${ }^{14)}$

注 3）本論文における絶対誤差 $\mathrm{AE}_{\mathrm{i}}$ と相対誤差 $\mathrm{RE}_{\mathrm{i}}$ は次の式による。

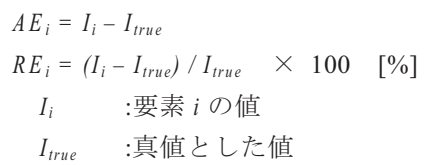

注 4） Kc、Cle および $\mathrm{Si}$ は次の式で定義される。

$\mathrm{Si}=\mathrm{Kc}+\mathrm{Cle} \mathrm{e}^{0.5}$

$K c=E e g / S e e g$

Eeg : 全天日射量 $\left[\mathrm{W} / \mathrm{m}^{2}\right]$,

Seeg $=0.84 \cdot E e o / m \cdot \exp (-0.0675 \cdot \mathrm{m})$ : 基準全天日射量 $\left[\mathrm{W} / \mathrm{m}^{2}\right]$

$m=1 /\left[\cos \gamma_{s z}+0.50572 \cdot\left(96.07995-\gamma_{s z}\right)^{-1.6364}\right]$ : 大気路程

$\gamma_{s z} \quad$ :太陽の天頂角 $[\mathrm{deg}]$

$E e o$ :大気外法線直達日射量 $\left[1,367 \mathrm{~W} / \mathrm{m}^{2}\right]$

$C l e=(1-C e) /\left(1-C e_{s}\right)$

$\mathrm{Ce}=\mathrm{Eed} / \mathrm{Eeg}:$ クラウド・レイショ

Eed : 天空日射量 $\left[\mathrm{W} / \mathrm{m}^{2}\right]$

$C e_{s}=0.01299+0.07698 \cdot m+0.003857 \cdot \mathrm{m}^{2}$

$+0.0001054 \cdot \mathrm{m}^{3}-0.000001031 \cdot \mathrm{m}^{4}:$ 基準クラウド・レイショ

\section{参考文献}

1) Grant, R.H.: The influence of the sky radiance distribution on the flux density in the shadow of a tree crown, Agric. Forest Meteorol., 35, pp.59-70, 1985.

2) Perez, R., Seals, R., and Michalsky, J.: All-weather model for sky luminance distribution - Preliminary configuration and validation, Solar Energy, Vol. 50, No. 3, pp. 235-245, 1993.

3) Igawa, N., et al.: Models of sky radiance distribution and sky luminance distribution, Solar Energy, Vol. 77, No. 2, pp. 137-157, 2004

4) Ward, G. J.: The RADIANCE lighting simulation and rendering system, International Conference on Computer Graphics and Interactive Techniques, pp. 459-472, 1994

5) Maamari, F., et al.: Reliable datasets for lighting programs validation, benchmark results, Excerpt from the Proceedings of CISBAT, pp. 241-246, 2003.

6) Mardaljevic, J.: Daylight simulation: validation, sky models and daylight coefficients, PhD Thesis, De Montfort University, 2000.

7) Anselmo, F. : “radiance@D.R.E.Am. :: irradiation + illumination maps", DREAM, available from < http://www.dream.unipa.it/dream/pub/ dot/anselmo/radiance/05.php>

8) Kittler, R.: Standard sky luminance patterns, their levels and occurrence probabilities J. Light \& Vis. Env., Vol. 22, No. 1, pp. 17-22. 1998.

9) 細淵勇人，吉田治典，上谷芳昭：天空放射輝度分布への CIE 標準一 般天空の流用と天空タイプの集約，日本建築学会環境系論文集， No.583, pp.29-36, 2004.

10）一八瀬雅之，石野久彌，郡公子，永田明寛：指向特性を考慮した放 射伝熱計算法, IBPSA-Japan 講演論文集(2005), 2005

11) 西田隆志，吉澤望，斉藤孝一郎，武田仁，堀慶朗：熱負荷計算にお ける開口部のモデル化手法の開発 〜その 1 Radiance を用いたブラ インドの日射特性值の算出〜，日本建築学会大会学術講演梗概集 D-2 分冊(2007), pp.15-16, 2007.

12) 前田敏男:発散光の強さ、入射光の強さ、反射特性関数および透過特 性関数の定義とその応用, 日本建築学会近畿支部研究報告集, pp.29-32, 1965

13) 日本建築学会：拡張アメダス気象データ 1981-2000, 鹿児島 TLO, 2005

14) Ward, G. J., Shakespeare , R.: Rendering with radiance: The art and science of lighting visualization, Morgan Kaufmann, 1998. 